\title{
The Effect of Steam-Flaked or Dry Ground Corn and Supplemental Phytic Acid on Phosphorus Partitioning and Ruminal Phytase Activity in Lactating Cows
}

\author{
A. D. Guyton, J. M. McKinney, and K. F. Knowlton \\ Department of Dairy Science \\ Virginia Polytechnic Institute and State University, Blacksburg 24061
}

\section{ABSTRACT}

The effect of starch source and phytic acid (PA) supplementation on phosphorus $(\mathrm{P})$ partitioning and ruminal phytase activity was evaluated in eight midlactation cows (four ruminally cannulated). Cows were randomly assigned to treatments in replicated $4 \times 4$ Latin squares with four 18-d periods. Diets included dry ground corn (DG) or steam-flaked corn (SF), with no supplemental P (L; $0.33 \% \mathrm{P})$ or supplemental purified $\mathrm{PA}(0.44 \% \mathrm{P})$ to provide additional $\mathrm{P}$ from a nonmineral source. Total collection of milk, urine, and feces was conducted on d 16 to 18 of each period. Ruminal fluid was sampled and ruminal $\mathrm{pH}$ measured every $8 \mathrm{~h}$ on d 17 and 18. Milk yield was unaffected by starch source, despite lower DMI by cows fed SF. Cows fed SF had increased DM digestibility compared with those fed DG, and tended to have higher efficiency of milk yield (1.40 vs. $1.35 \mathrm{~kg}$ of milk/kg of DMI). Intake and fecal excretion of $\mathrm{P}$ was lower in cows fed SF than in cows fed DG. In cows fed SF, milk $\mathrm{P}$ as a percentage of $\mathrm{P}$ intake increased compared with cows fed DG. Ruminal $\mathrm{pH}$ was unaffected by diet, but milk fat content was lower for cows fed SF. Milk yield, DMI, and feed to milk ratio were not affected by supplementation with PA. Although cows fed PA had increased P intake compared with cows fed low $\mathrm{P}$ diet, increased $\mathrm{P}$ excretion resulted in no differences in apparent $\mathrm{P}$ digestibility. Phosphorus balance tended to be higher in cows fed PA, but milk $\mathrm{P}$ as a percentage of intake was reduced. The interaction of starch source and PA affected ruminal phytase activity. Altering starch source to improve efficiency of milk yield in lactating dairy cows may help reduce $\mathrm{P}$ losses from dairy farms.

(Key words: phosphorus excretion, phytase activity, starch digestibility)

Abbreviation key: SF = steam-flaked corn, $\mathbf{D G}=$ dry ground corn, $\mathbf{P A}=$ phytic acid, $\mathbf{L}=$ low $\mathbf{P}$.

Received February 12, 2002.

Accepted May 19, 2003.

Corresponding author: K. F. Knowlton; e-mail: knowlton@vt.edu.

\section{INTRODUCTION}

Phosphorus is brought onto farms through feed and fertilizer. Roughly 30 to $50 \%$ of feed P is captured in meat and milk, and 50 to $70 \%$ is excreted in manure (Morse et al., 1992; Knowlton et al., 2001; Knowlton and Herbein, 2002). If manure $\mathrm{P}$ application is greater than crop $\mathrm{P}$ uptake, $\mathrm{P}$ accumulates in the soil and may eventually run off into nearby surface water, causing eutrophication and algae blooms. Algae blooms shade aquatic vegetation and reduce photosynthesis by plants. The decomposition of algae consumes dissolved oxygen in water, impairing its usefulness for recreation, drinking, fishing, and industry (Sims et al., 1998).

Animal agriculture can be a major source of $\mathrm{P}$ pollution. Smith and Alexander (2000) estimated that the median contribution of animal agriculture to $\mathrm{P}$ losses in major watersheds ranged from 7 to $48 \%$ of total $\mathrm{P}$ losses. These losses were calculated with a model using measured stream water quality data and spatial data on sources, landscape characteristics, and stream properties. The relative importance of different nutrient sources varies greatly in different regions of the United States, with animal agriculture a relatively less important contributor in the populous Northeast and Great Lakes. Concerns with P contamination of surface water have brought about new, stricter legislative policies limiting manure P application (Water Quality Improvement Act of 1998; Virginia Poultry Waste Management Program, 1999). Under P-based regulations, many farms will have to reduce manure application to cropland.

Reduced feeding of dietary $\mathrm{P}$ can reduce $\mathrm{P}$ excretion (Morse et al., 1992a; Wu and Satter, 2000; Wu et al., 2000; Knowlton et al., 2001; Knowlton and Herbein, 2002), reducing potential $P$ losses from farms. Previous work suggests that feeding more digestible starch sources may also decrease P excretion. Guyton et al. (2000) observed that in cows fed diets with more digestible starch sources (high moisture vs. dry ground corn, corn vs. barley) fecal $\mathrm{P}$ as a percentage of intake was 4 to 10 percentage units lower. Similarly, Glenn et al. (1998) observed that replacing dried ground corn with 
increasing proportions of high-moisture corn decreased fecal $\mathrm{P}$ excretion despite similar $\mathrm{P}$ intake.

Whereas the mechanism for decreased $\mathrm{P}$ excretion with more ruminally available starch sources is unclear, one possible explanation is that availability of dietary starch may affect ruminal phytase activity. Approximately 65 to $70 \%$ of the total $\mathrm{P}$ in cereal grains is organically bound in phytate P (Nelson et al., 1968; Morse et al., 1992b). Phytate $\mathrm{P}$ is more available to ruminants than to nonruminants, because ruminal microorganisms possess the enzyme phytase (Yanke et al., 1998). Phytase breaks the phosphate groups from the inositol ring, making the $\mathrm{P}$ more available for absorption in the small intestine (Morse et al., 1992b; Yanke et al., 1998).

Our objective was to evaluate the effect of starch source, dietary phytate $\mathrm{P}$ content, and their interaction on $\mathrm{P}$ partitioning and excretion and ruminal phytase activity in lactating dairy cows. We hypothesized that the more digestible starch source, steam-flaked corn (SF), would increase ruminal phytase activity and decrease $\mathrm{P}$ excretion compared with cows fed dry ground corn (DG), and that this increased phytase activity would be particularly of benefit in diets with higher phytic acid $\mathrm{P}$ content.

\section{MATERIALS AND METHODS}

\section{Cows and Diets}

Eight midlactation Holstein cows $(113 \pm 46.3$ DIM $)$ were randomly assigned to experimental diets containing SF or DG corn, with one of two concentrations of dietary P. Diets were formulated to meet the nutrient requirements of the cow according to the $1989 \mathrm{NRC}$ (National Research Council, 1989). Four of the cows were equipped with plastisol rumen cannulas $(10.2 \mathrm{~cm}$ i.d.; Bar Diamond Cannula, Bar Diamond Inc., Parma, ID). This experiment was conducted under approval from the Virginia Tech Animal Care Committee.

Treatment diets contained $61 \%$ forage. The low $(\mathbf{L})$ $P$ diets (DG-L, SF-L) contained 0.33\% P. Purified phytic acid (PA; $19.8 \%$ P, Biosynth International Inc., Naperville, IL) was added to the concentrate mix to provide additional $\mathrm{P}$ from a nonmineral source for the high $\mathrm{P}$ diets (DG-PA, SF-PA; $0.44 \%$ P). Flake density of the $\mathrm{SF}$ corn was $386 \mathrm{~g} / \mathrm{L}$. Ingredient composition of the diets is listed in Table 1.

\section{Experimental Design and Sampling}

Cows were grouped by calving date and previous lactation mature equivalent milk yield and assigned to one of two $4 \times 4$ Latin squares. Squares were balanced for carryover effects. A total of two cows missed one
Table 1. Ingredient composition of diets.

\begin{tabular}{|c|c|c|c|c|}
\hline & \multicolumn{2}{|c|}{ Dry ground corn } & \multicolumn{2}{|c|}{ Steam-flaked corn } \\
\hline & Low $\mathrm{P}$ & Phytic acid & Low $\mathrm{P}$ & Phytic acid \\
\hline & & $-\%$ of $\mathrm{d}$ & et DM & \\
\hline \multicolumn{5}{|l|}{ Diet ingredients } \\
\hline Alfalfa silage & 46.1 & 45.8 & 46.1 & 45.8 \\
\hline Corn silage & 15.4 & 15.3 & 15.4 & 15.3 \\
\hline Ground corn & 28.8 & 28.7 & 0.0 & 0.0 \\
\hline Steam flaked corn & 0.0 & 0.0 & 28.8 & 28.7 \\
\hline Concentrate mixture & 9.7 & 10.2 & 9.7 & 10.2 \\
\hline \multicolumn{5}{|l|}{ Concentrate ingredients } \\
\hline Soybean meal, $48 \%$ & 42.2 & 40.1 & 42.2 & 40.1 \\
\hline Expeller soybean meal $^{1}$ & 28.1 & 26.7 & 28.1 & 26.7 \\
\hline Mineral mix ${ }^{2}$ & 18.5 & 17.6 & 18.5 & 17.6 \\
\hline Sodium bicarbonate & 5.3 & 5.0 & 5.3 & 5.0 \\
\hline Limestone & 4.8 & 4.6 & 4.8 & 4.6 \\
\hline Salt-white & 1.1 & 1.0 & 1.1 & 1.0 \\
\hline Phytic acid & 0.0 & 5.0 & 0.0 & 5.0 \\
\hline
\end{tabular}

${ }^{1}$ Soyplus, West Central Soy, Ralston, IA.

${ }^{2}$ Each $\mathrm{kg}$ contained $25 \mathrm{~g}$ of $\mathrm{Mg}, 10 \mathrm{mg}$ of $\mathrm{Co}, 500 \mathrm{mg}$ of $\mathrm{Cu}, 40 \mathrm{mg}$ of I, $2.25 \mathrm{~g}$ of Mn, $15 \mathrm{mg}$ of Se, $2.5 \mathrm{~g}$ of $\mathrm{Zn}, 331,000 \mathrm{IU}$ of vitamin A, 110,200 IU of vitamin D, and 1323 IU of vitamin $\mathrm{E}$.

collection period each because of clinical mastitis. The first of these cows missed period 1, whereas on the DGPA treatment. The milk yield of this cow returned to normal by $\mathrm{d} 2$ of period 2 , and she was collected as usual in periods 2,3 , and 4 . The other mastitic cow missed period 4 while on the SF-L treatment.

Each experimental period lasted $18 \mathrm{~d}$. Cows were fed in Calan doors for the first $14 \mathrm{~d}$ of each period and were moved to individual stalls on d 15 for total collection of feces, urine, and milk. Cows were fed once daily at $0800 \mathrm{~h}$ and milked at 0700 and $1900 \mathrm{~h}$. Feed was offered 5 to $10 \%$ in excess of previous day's intake (wet basis).

On d 15, a sterile Foley urine catheter (22 French, 75 cc; C.R. Bard, Inc., Covington, GA) was inserted into the urethra for total collection of urine. All excreted urine, feces, and milk were collected on $\mathrm{d} 16,17$, and 18. Urine was weighed at 4 -h intervals, acidified (22 $\mathrm{ml}$ of $6 \mathrm{~N} \mathrm{HCl} / \mathrm{kg}$ of urine), pooled, subsampled after $24 \mathrm{~h}$, and stored frozen for later analysis. All excreted feces were collected at 4-h intervals and stored in a sealed container, then weighed, thoroughly mixed, and subsampled daily. Feed ingredients (forages and concentrates) were sampled once each week, and feed refusals were weighed and sampled daily. On d 16, 17, and 18, feed offered and refused were measured, total milk weights were recorded, and milk was sampled at six consecutive milkings.

Ruminal fluid samples were collected at 8-h intervals on d 16 and 17 for analysis of VFA. Sampling times were shifted forward by $4 \mathrm{~h}$ on $\mathrm{d} 17$ so that samples collected ( $n=6$ per cow per period) represented every 
$4 \mathrm{~h}$ of a $24-\mathrm{h}$ period. These ruminal fluid samples were collected manually from six locations in the rumen, then filtered through four layers of cheesecloth. Filtered ruminal fluid samples were acidified $(0.2 \mathrm{ml}$ of $3.7 \mathrm{~N}$ $\mathrm{H}_{3} \mathrm{PO}_{4}$ per ml) and stored frozen. Ruminal $\mathrm{pH}$ was measured at each ruminal fluid sampling time with a portable $\mathrm{pH}$ meter (VWR brand $\mathrm{pH} / \mathrm{mV} / \mathrm{Temperature} \mathrm{Meter,}$ model 2000/3000; VWR Scientific Products, South Plainfield, NJ.). The electrode (Orion $\mathrm{Ag} / \mathrm{AgCl}$ SureFlow electrode, model 9172 BN; Orion Research Inc., Beverly, MA) was calibrated at each sampling time and inserted into the ventral sac of the rumen.

Additional ruminal fluid (1 L per cow) was collected on $\mathrm{d} 17$ each period at 0900 and $1300 \mathrm{~h}$ for analysis of phytase activity. Following collection, ruminal fluid was immediately processed in an industrial size blender at low speed for $1 \mathrm{~min}$ and filtered through four layers of cheesecloth; both steps were conducted under $\mathrm{CO}_{2}$. Samples were immediately analyzed for phytase activity as outlined below.

Ruminal contents were measured and sampled on $\mathrm{d}$ 18 of each collection week at $0800 \mathrm{~h}$ for measurement of ruminal nutrient pool size. Rumens were evacuated manually, and a $10 \%$ aliquot of digesta was separated during collection for ease of subsampling. All evacuated contents were weighed. The aliquot was mixed by hand and subsampled. Ruminal contents were returned to the cow following sampling and measurement.

\section{Laboratory Analysis}

Samples of feed refusals, feed ingredients, feces, and ruminal contents were dried to constant weight at $60^{\circ} \mathrm{C}$ in a forced-air drying oven (Wisconsin Oven, Memmert; Schwabach, Germany). Dried samples were ground through a 1-mm screen in a Wiley Mill (Arthur H. Thomas, Philadelphia, PA). Feed and feed refusal samples were analyzed in duplicate for $\mathrm{N}, \mathrm{P}, \mathrm{Ca}, \mathrm{Mg}$ (AOAC, 1984 ), and NDF and ADF sequentially with $\alpha$-amylase (Van Soest et al., 1991). Ash content of feed samples was measured by incineration at $500^{\circ} \mathrm{C}$ for $6 \mathrm{~h}$ in a muffle furnace. Starch content of feed was determined by a two-step enzymatic method (Holm et al., 1986) with a YSI biochemistry analyzer (YSI Inc., Yellow Springs, $\mathrm{OH}$ ) to read dextrose release (Cumberland Valley Analytical Services, Hagerstown, MD). Feces samples were analyzed for P, starch and NDF as described above, whereas rumen contents samples were analyzed for $\mathrm{P}$ and NDF. Ruminal pool sizes (kg) of DM, P, and NDF were calculated by multiplying the concentrations of each by the rumen digesta DM weight (kg). Ruminal turnover time of DM, NDF, and $\mathrm{P}$ (h, the sum of nutrient removal by digestion in and passage from the rumen) was calculated by dividing nutrient pool size $(\mathrm{kg})$ by nutrient intake (kg/d) and multiplying by $24 \mathrm{~h} / \mathrm{d}$. Urine samples were analyzed for $\mathrm{P}$ (AOAC, 1984). Milk samples were analyzed for fat, protein, total solids, SNF (Dairy Herd Improvement Association, Blacksburg, VA), and P (AOAC, 1984).

The VFA content of ruminal fluid samples $(n=6$ per cow per period) were measured via gas chromatography (Hewlett Packard model 5890 Series II fitted with an autosampler) with a flame-ionization detector (Agilent Technologies Inc., Wilmington, DE). Individual VFA were separated using a DB-WAXetr column $(30 \mathrm{~m} \times$ $0.53 \mathrm{~mm}$ ID , $1-\mu \mathrm{m}$ film thickness), and quantified with respect to an internal standard ( $1 \mathrm{ml}$ of $30 \mathrm{mM}$ 4-methylvaleric acid) prepared before the sample was preserved. A split injection (51:1) of $0.5 \mu \mathrm{l}$ was used. Injector and detector temperatures were $250^{\circ} \mathrm{C}$. Initial oven temperature of $125^{\circ} \mathrm{C}$ was held for $5 \mathrm{~min}$ and increased to $180^{\circ} \mathrm{C}$ at a rate of $15^{\circ} \mathrm{C} / \mathrm{min}$ and held for $6 \mathrm{~min}$. The total run time was 14.6 min per sample. High purity helium was the carrier gas with a flow rate of $4.2 \mathrm{ml} /$ min. Inlet pressure was held constant at 4.4 psi.

For quantification of ruminal phytase activity, processed, unacidified ruminal fluid $(\mathrm{n}=2$ per cow per period) was centrifuged at $1000 \times g$ for $5 \mathrm{~min}$ at 15 to $20^{\circ} \mathrm{C}$ to remove feed particles and protozoa. The supernatant was decanted and centrifuged for a second time for $5 \mathrm{~min}$ at $1000 \times \mathrm{g}$. The supernatant was incubated with a $9 \mathrm{~m} M$ phytic acid solution $(0.1 \mathrm{ml}$ of ruminal fluid in $3 \mathrm{ml}$ of PA solution; BASF, 1996). The PA solution was comprised of phytic acid in a $0.25 M$ acetate buffer at $\mathrm{pH}$ 5.5. Phytase activity was measured as inorganic $\mathrm{P}$ released, $\mu \mathrm{mol}$ per minute per milliliter of ruminal fluid, measured using inductively coupled plasma atomic emission spectrometry (Virginia Tech Soil Testing Lab, Blacksburg, VA). Conditions of the assay, including ratio of ruminal fluid to PA solution, were established to measure maximal rate of Pi release.

\section{Statistical Analysis}

All data except ruminal VFA and $\mathrm{pH}$ were analyzed using PROC MIXED procedures of SAS (SAS Institute, 1999), with the model:

$$
\begin{aligned}
\mathrm{Y}_{\mathrm{ijk} \mathrm{k}}=\mu & +\mathrm{G}_{\mathrm{i}}+\mathrm{C}_{\mathrm{j}}(\mathrm{G})_{\mathrm{i}}+\mathrm{D}_{\mathrm{k}}+\mathrm{S}_{\mathrm{l}}+\mathrm{P}_{\mathrm{m}} \\
& +(\mathrm{S} * \mathrm{P})_{\mathrm{lm}}+\mathrm{e}_{\mathrm{ijk} \mathrm{k}},
\end{aligned}
$$

where

$$
\begin{aligned}
\mu & =\text { overall mean, } \\
\mathrm{G}_{\mathrm{i}} & =\text { random effect of square }(\mathrm{i}=1 \text { to } 2), \\
\mathrm{C}_{\mathrm{j}}(\mathrm{G})_{\mathrm{i}}= & \text { random effect of cow within square }(\mathrm{j}=1 \text { to } \\
& 4), \\
\mathrm{D}_{\mathrm{k}} & =\text { fixed effect of period }(\mathrm{k}=1 \text { to } 4),
\end{aligned}
$$


Table 2. Nutrient composition of diets.

\begin{tabular}{|c|c|c|c|c|c|c|c|c|}
\hline & \multicolumn{2}{|c|}{ Dry ground corn } & \multicolumn{2}{|c|}{ Steam-flaked corn } & \multirow[b]{2}{*}{ SEM } & \multicolumn{3}{|c|}{$P<$} \\
\hline & Low $\mathrm{P}$ & $\mathrm{PA}^{1}$ & Low $\mathrm{P}$ & $\mathrm{PA}$ & & Starch & $\mathrm{P}$ & Starch $\times \mathrm{P}$ \\
\hline & \multicolumn{8}{|c|}{$\overline{ } \%$ of diet DM -} \\
\hline NDF & 31.7 & 31.5 & 31.7 & 31.4 & 0.46 & 0.91 & 0.61 & 0.90 \\
\hline $\mathrm{ADF}$ & 21.5 & 21.2 & 21.8 & 21.6 & 0.48 & 0.51 & 0.66 & 0.89 \\
\hline Ash & 7.65 & 7.91 & 7.55 & 7.84 & 0.08 & 0.31 & 0.05 & 0.81 \\
\hline CP & 17.2 & 17.2 & 17.1 & 17.1 & 0.20 & 0.50 & 0.83 & 0.80 \\
\hline $\mathrm{P}$ & 0.35 & 0.45 & 0.31 & 0.42 & 0.01 & 0.01 & 0.01 & 0.79 \\
\hline $\mathrm{Ca}$ & 0.78 & 0.81 & 0.78 & 0.82 & 0.02 & 0.62 & 0.04 & 0.85 \\
\hline $\mathrm{Mg}$ & 0.33 & 0.35 & 0.33 & 0.34 & 0.01 & 0.67 & 0.29 & 0.84 \\
\hline Starch & 24.5 & 24.4 & 25.1 & 24.9 & 0.42 & 0.17 & 0.67 & 0.91 \\
\hline
\end{tabular}

${ }^{1} \mathrm{~A}=$ phytic acid.

$\mathrm{S}_{1}=$ fixed effect of starch source $(1=1$ to 2$)$,

$\mathrm{P}_{\mathrm{m}}=$ fixed effect of PA supplementation $(\mathrm{m}=1$ to 2 ),

$(\mathrm{S} * \mathrm{P})_{\operatorname{lm}}=$ effect of interaction of $\mathrm{S}_{1}$ and $\mathrm{P}_{\mathrm{m}}$, and

$\mathrm{e}_{\mathrm{ijk} \mathrm{km}}=$ residual error.

Residual error was used to test main effects and interactions. Differences were declared significant at $P<$ 0.05 and trends at $P<0.10$. Results are reported as least squares means.

Ruminal VFA and $\mathrm{pH}$ data were analyzed using PROC MIXED of SAS (SAS Institute, 1999), with the model

$$
\begin{gathered}
\mathrm{Y}_{\mathrm{ijklm}}=\mu+\mathrm{C}_{\mathrm{i}}+\mathrm{D}_{\mathrm{j}}+\mathrm{S}_{\mathrm{k}}+\mathrm{P}_{\mathrm{l}}+(\mathrm{S} * \mathrm{P})_{\mathrm{kl}}+\mathrm{H}_{\mathrm{m}} \\
+(\mathrm{H} * \mathrm{~S})_{\mathrm{km}}+(\mathrm{H} * \mathrm{P})_{\mathrm{lm}}+(\mathrm{H} * \mathrm{~S} * \mathrm{P})_{\mathrm{klm}}+\mathrm{e}_{\mathrm{ijkl}},
\end{gathered}
$$

where

$$
\begin{aligned}
\mu= & \text { overall mean, } \\
\mathrm{C}_{\mathrm{j}}= & \text { random effect of cow }(\mathrm{i}=1 \text { to } 4), \\
\mathrm{D}_{\mathrm{j}}= & \text { fixed effect of period }(\mathrm{i}=1 \text { to } 4), \\
\mathrm{S}_{\mathrm{k}}= & \text { fixed effect of starch source }(\mathrm{k}=1 \text { to } 2), \\
\mathrm{P}_{1}= & \text { fixed effect of PA supplementation }(\mathrm{l}= \\
& 1 \text { to } 2),
\end{aligned}
$$$$
(\mathrm{S} * \mathrm{P})_{\mathrm{kl}}=\text { effect of interaction of } \mathrm{S}_{\mathrm{k}} \text { and } \mathrm{P}_{\mathrm{l}} \text {, and }
$$$$
\mathrm{H}_{\mathrm{m}}=\text { fixed effect of hour of sampling, }
$$$$
(\mathrm{H} * \mathrm{~S})_{\mathrm{km}}=\text { effect of interaction of } \mathrm{H}_{\mathrm{m}} * \mathrm{~S}_{\mathrm{k}} \text {, }
$$

$(\mathrm{H} * \mathrm{P})_{\mathrm{lm}}=$ effect of interaction of $\mathrm{H}_{\mathrm{m}}$ and $\mathrm{P}_{\mathrm{l}}$,

$$
(\mathrm{H} * \mathrm{~S} * \mathrm{P})_{\mathrm{klm}}=\text { effect of interaction of } \mathrm{H}_{\mathrm{m}}, \mathrm{S}_{\mathrm{k}} \text { and } \mathrm{P}_{\mathrm{l}} \text {, }
$$
and

$$
\mathrm{e}_{\mathrm{ijklm}}=\text { residual error. }
$$

For VFA and $\mathrm{pH}$ data, cow was the error term used to test the effect of starch source and PA supplementation. Residual error was used to test the effects of hour of sampling and its interaction with starch source and PA supplementation. Differences were declared significant at $P<0.05$ and trends at $P<0.10$. Results are reported as least squares means.
As noted above, two cow-period observations were not collected because cows were sick during the collection period (one cow in period 1 , one cow in period 4). This missing data is accommodated in PROC Mixed using a restricted maximum likelihood estimation technique.

\section{RESULTS AND DISCUSSION}

\section{Nutrient Composition of Diets}

The nutrient composition of the diets is listed in Table 2. The $\mathrm{L}$ and PA diets differed in dietary $\mathrm{P}$ content as intended. Results of chemical analysis also indicated small differences in dietary ash and $\mathrm{Ca}$. Ash content was higher in the PA diet than in the low P diet due to the addition of phytic acid. The PA diet also had a slightly higher Ca content than the low $\mathrm{P}$ diet. The SF diets were lower in $\mathrm{P}$ content compared with the DG diets because the SF corn had a lower P content than did the DG corn. Dried ground corn and SF corn were not from the same source, so the effects of starch source (corn grain processing) may be confounded with differences in corn grain genotype, growing environment, or harvest.

\section{Phosphorus Digestion and Partitioning}

Effect of starch source. Cows fed SF had lower P intake and excretion of fecal and total $\mathrm{P}$ compared with cows fed DG (Table 3). Apparent P digestibility was not affected by starch source. The reduction in $\mathrm{P}$ intake was due to the significant reduction in DMI with SF (Table 4, discussed below), and this reduced $\mathrm{P}$ intake caused reduced P excretion. Guyton et al. (2000) observed that cows fed diets with a more digestible starch source, high moisture corn, had decreased fecal $\mathrm{P}$ as a proportion of $\mathrm{P}$ intake compared with those fed diets containing dry ground corn. Dry matter intake and $\mathrm{P}$ intake were similar in that study. Also, Glenn et al. (1998) observed that replacing dried ground corn with 
Table 3. Effect of starch source and supplemental phytic acid (PA) on P partitioning in eight lactating Holstein cows.

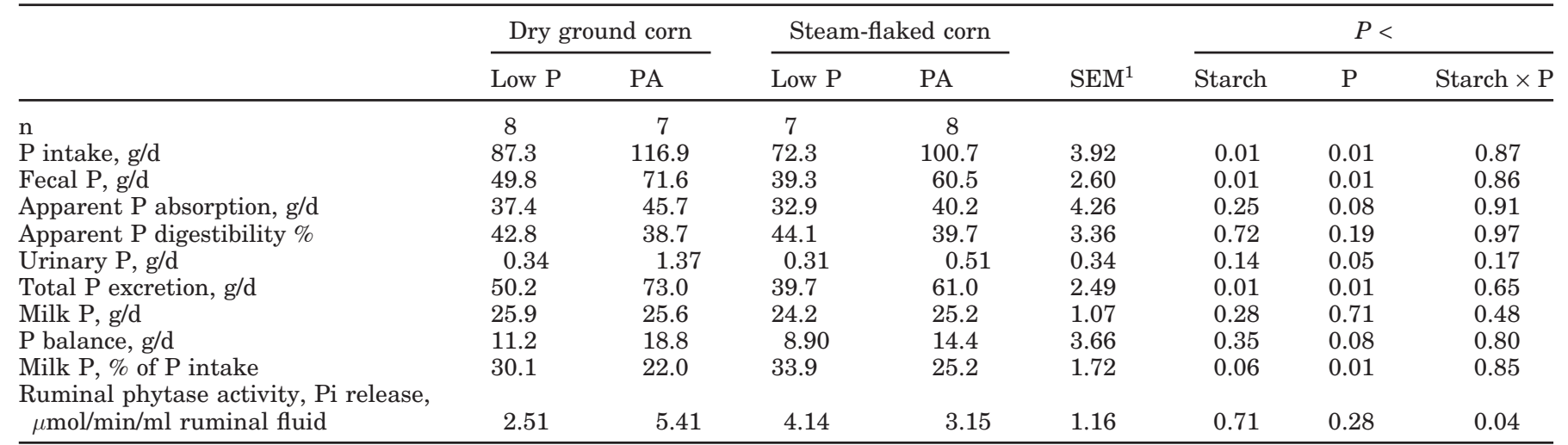

${ }^{1}$ Unequal n, largest SEM $(\mathrm{n}=7)$ reported.

increasing proportions of high moisture corn decreased fecal $\mathrm{P}$ excretion despite similar $\mathrm{P}$ intake.

Our results are not consistent with the observations of Guyton et al. (2000) and Glenn et al. (1998), as apparent $P$ digestibility was unaffected by starch source. The lack of effect of starch source on apparent $P$ digestibility is also unusual given that $\mathrm{P}$ intake was affected. Other studies report a decrease in apparent $\mathrm{P}$ digestibility with increased P intake (Wu et al., 2001; Knowlton and Herbein, 2002). This is usually explained as a result of increased recycling of $\mathrm{P}$ to the gut via saliva.

Consistent with our results, however, Knowlton et al. (2001) observed no effect of $P$ intake on apparent $P$ digestibility when $\mathrm{P}$ intake was increased via increased DMI in cows fed $\mathrm{P}$ from a mineral source rather than with wheat bran. Also, Wu et al. (2000) observed no effect of $\mathrm{P}$ intake on apparent $\mathrm{P}$ digestibility in four of six sampling periods throughout lactation. Possible explanations for the discrepancy between results of these studies include differences in $\mathrm{P}$ intake, stage of lactation, and milk yield.

Cows fed SF had similar milk P, P balance, and ruminal phytase activity compared with those fed DG (Table 3). Milk $\mathrm{P}$ as a percentage of $\mathrm{P}$ intake tended to be higher when cows were fed SF ( 14.8 vs. $13.0 \% ; P<0.06)$ compared with cows fed DG. This was due to the lower $\mathrm{P}$ intake of these cows. Morse et al. (1992a), Knowlton et al. (2001), and Knowlton and Herbein (2002) all reported an increase in milk $\mathrm{P}$ as percentage of $\mathrm{P}$ intake when cows consumed less dietary P.

The lack of effect of starch source on ruminal phytase activity contradicts our original hypothesis. The difference in total tract starch digestibility due to starch source was only $\sim 1.5$ units in our study. The magnitude of this difference is too small to draw any substantive conclusion about the effect of ruminal starch digestion on ruminal phytase activity. More extensive research comparing more divergent dietary treatments is needed.

Effect of phytic acid supplementation. Cows fed PA had increased P intake, and increased fecal, urinary, and total $\mathrm{P}$ excretion compared with cows fed L (Table 3). Morse et al. (1992a) reported an increase in fecal and urinary $\mathrm{P}$ excretion when cows were fed a high $\mathrm{P}$ $\operatorname{diet}(0.56 \% \mathrm{P})$ compared with medium $(0.41 \% \mathrm{P})$ and low $\mathrm{P}(0.30 \% \mathrm{P})$ diets. Other studies have observed an increase in fecal and urinary $\mathrm{P}$ excretion with increased

Table 4. Effect of starch source and supplemental phytic acid (PA) on DMI, milk yield, milk composition, and feed efficiency of eight lactating Holstein cows.

\begin{tabular}{|c|c|c|c|c|c|c|c|c|}
\hline & \multicolumn{2}{|c|}{ Dry ground corn } & \multicolumn{2}{|c|}{ Steam-flaked corn } & \multirow[b]{2}{*}{$\mathrm{SEM}^{1}$} & \multicolumn{3}{|c|}{$P<$} \\
\hline & Low $\mathrm{P}$ & PA & Low $\mathrm{P}$ & $\mathrm{PA}$ & & Starch & $\mathrm{P}$ & Starch $\times P$ \\
\hline DMI, kg/d & 25.1 & 26.4 & 24.2 & 23.7 & 0.95 & 0.03 & 0.63 & 0.25 \\
\hline Milk yield, kg/d & 33.8 & 34.0 & 33.1 & 33.5 & 0.94 & 0.50 & 0.74 & 1.0 \\
\hline Milk fat, $\mathrm{kg} / \mathrm{d}$ & 1.23 & 1.25 & 1.11 & 1.18 & 0.04 & 0.02 & 0.27 & 0.51 \\
\hline Protein, kg/d & 1.15 & 1.20 & 1.15 & 1.18 & 0.03 & 0.69 & 0.18 & 0.68 \\
\hline Lactose, $\mathrm{kg} / \mathrm{d}$ & 1.82 & 1.89 & 1.90 & 1.84 & 0.07 & 0.84 & 0.96 & 0.37 \\
\hline $\mathrm{SNF}, \mathrm{kg} / \mathrm{d}$ & 3.34 & 3.47 & 3.40 & 3.30 & 0.10 & 0.53 & 0.89 & 0.25 \\
\hline Milk yield/DMI & 1.35 & 1.31 & 1.38 & 1.42 & 0.10 & 0.07 & 0.96 & 0.23 \\
\hline
\end{tabular}

\footnotetext{
${ }^{1}$ Unequal $\mathrm{n}$, largest SEM $(\mathrm{n}=7)$ reported.
} 


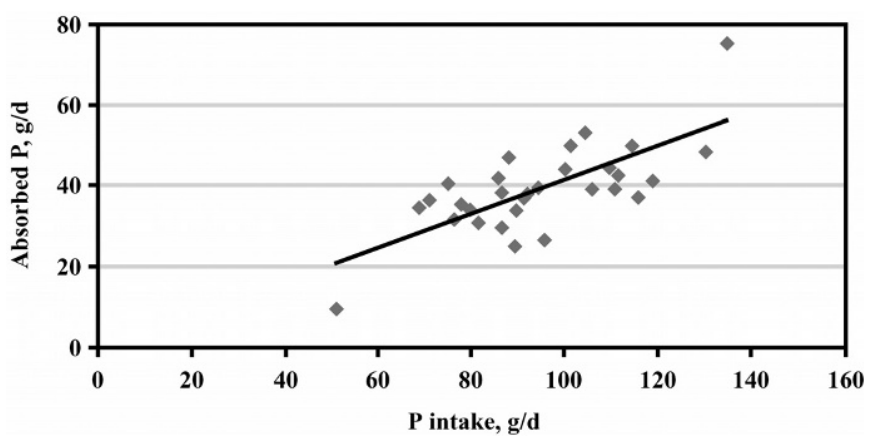

Figure 1. Relationship between $\mathrm{P}$ intake $(\mathrm{X})$ and apparently absorbed $\mathrm{P}(\mathrm{Y})$ in eight lactating Holstein cows: $\mathrm{Y}=0.423 \mathrm{X}-0.764 ; \mathrm{r}^{2}$ $=0.52$.

dietary P intake (Wu et al., 2000; Knowlton et al., 2001; Wu et al., 2001; Knowlton and Herbein, 2002).

Apparent $\mathrm{P}$ digestibility was unaffected by PA supplementation (Table 3). Knowlton and Herbein (2002) reported a decline in apparent $\mathrm{P}$ digestibility from 49 to $33 \%$ with increasing dietary $\mathrm{P}$ intake. Cows supplemented with organic $\mathrm{P}$ in the form of wheat bran had apparent $\mathrm{P}$ digestibility similar to cows supplemented with an inorganic $\mathrm{P}$ source, mono- and di-calcium phosphate $($ mean $=45 \%$; Knowlton et al. 2001). Morse et al. (1992b) reported that $99 \%$ of the phytate $\mathrm{P}$ was hydrolyzed in lactating cows, based on phytic acid intake and excretion in cows fed diets containing $0.38 \%$ phytate $\mathrm{P}$. Also, 12 -h in vitro phytate $\mathrm{P}$ degradation was greater than $95 \%$ for a variety of cereal grains, including wheat midds, rice bran, hominy, soybean meal, and dried distillers' grains (Morse et al., 1992b). The similar apparent $\mathrm{P}$ digestibilities in response to diets fed in this study indicated that availability of supplemental phytic acid $\mathrm{P}$ was similar to $\mathrm{P}$ availability of the basal diet.

Milk P secretion was unaffected by PA supplementation, but milk $\mathrm{P}$ as a percentage of $\mathrm{P}$ intake decreased when cows were fed PA compared with the low P diet (11.8 vs. $16.0 \%$; Table 3). Morse et al. (1992a), Knowlton et al. (2001), and Knowlton and Herbein (2002) also observed that milk $\mathrm{P}$ as a percentage of $\mathrm{P}$ intake decreased with an increase in dietary $\mathrm{P}$ content, as the $\mathrm{P}$ content of milk is relatively constant.

Phosphorus balance tended to be higher in cows fed the PA diet compared with cows fed the low $\mathrm{P} \operatorname{diet}(P$ $<0.08$ ) and was positive in all but two cow periods (Figure 2). Intake of $\mathrm{P}$ accounted for $52 \%$ of the variation in absorbed $\mathrm{P}$ (Figure 1) and $\mathrm{P}$ balance (Figure 2). The observation of net $\mathrm{P}$ retention (positive $\mathrm{P}$ balance) was despite the apparent marginal P deficiency of cows on the low $\mathrm{P}$ diet. That diet supplied approximately $90 \%$ of required absorbable P (National Research Council,

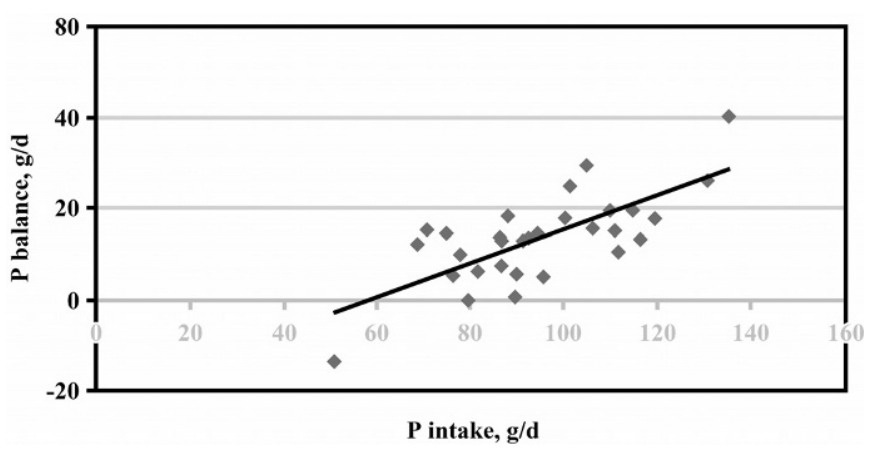

Figure 2. Relationship between $\mathrm{P}$ intake $(\mathrm{X})$ and $\mathrm{P}$ balance $(\mathrm{Y})$ in eight lactating Holstein cows: $\mathrm{Y}=0.376 \mathrm{X}-22.2 ; \mathrm{r}^{2}=0.52$.

2001). Diets containing supplemental PA were $20 \%$ in excess of published $\mathrm{P}$ requirements, assuming availability of $\mathrm{P}$ from PA of $70 \%$, similar to that of concentrate ingredients.

Supplementation with PA had no effect on ruminal phytase activity (Table 3). Variation was large due in part to limited numbers of observations. Godoy and Meschy (2001) observed an increase in phytate $P$ availability within both high and low $\mathrm{P}$ diets when an organic P buffer (corn sodium phytate) was compared to an inorganic buffer (monosodium phosphate) in a semicontinuous culture system (RUSITEC) that used ruminal fluid from goats. They observed a buffer effect on phytase activity but no effect of diet. They concluded that ruminal phytase activity decreases when there is more inorganic $\mathrm{P}$ available for utilization by ruminal microbes.

Effect of interaction of starch source and phytic acid supplementation. No effect of the interaction of starch source and PA supplementation was observed on $\mathrm{P}$ intake, fecal $\mathrm{P}$ excretion, urinary $\mathrm{P}$ excretion, milk $\mathrm{P}$ secretion, apparent $\mathrm{P}$ digestibility, or $\mathrm{P}$ balance (Table 3). An interaction of starch source and PA supplementation was observed for ruminal phytase activity. The direction of the response to PA supplementation differed with starch source. Within the DG diet, ruminal phytase activity was numerically greater in cows fed PA than in cows fed the low P diet, whereas within the SF diet, phytase activity was similar with and without PA supplementation.

Few studies have evaluated the effect of diet on ruminal phytase activity. Yanke et al. (1998) observed a linear increase in ruminal phytase activity with decreasing forage:concentrate ratio in steers fed either 100\% hay, $55 \%$ barley: $45 \%$ hay or $90 \%$ barley: $10 \%$ hay (4.3, 8.1, and 17.5 units/ml of ruminal fluid). In a continuous culture fermenter utilizing ruminal fluid from goats, Godoy and Meschy (2001) observed an increase in phytate $\mathrm{P}$ availability with an organic $\mathrm{P}$ buffer com- 
Table 5. Effect of starch source and supplemental dietary phytic acid (PA) on ruminal VFA concentrations and pH in four lactating Holstein cows.

\begin{tabular}{|c|c|c|c|c|c|c|c|c|}
\hline & \multicolumn{2}{|c|}{ Dry ground corn } & \multicolumn{2}{|c|}{ Steam-flaked corn } & SEM $^{1}$ & \multicolumn{3}{|c|}{$P<$} \\
\hline $\mathrm{n}$ & 4 & 4 & 3 & 4 & & & & \\
\hline \multicolumn{9}{|c|}{ VFA concentration, $\mathrm{mol} / 100 \mathrm{~mol}$} \\
\hline Acetate & 69.1 & 69.5 & 67.2 & 68.0 & 0.68 & 0.01 & 0.13 & 0.59 \\
\hline Propionate & 16.3 & 16.5 & 18.0 & 17.4 & 0.27 & 0.01 & 0.42 & 0.10 \\
\hline Valerate & 1.43 & 1.44 & 1.50 & 1.41 & 0.05 & 0.51 & 0.28 & 0.12 \\
\hline Acetate:Propionate & 4.26 & 4.25 & 3.77 & 3.92 & 0.10 & 0.01 & 0.37 & 0.29 \\
\hline Total VFA, mM & 152.1 & 152.4 & 151.0 & 152.1 & 3.20 & 0.80 & 0.79 & 0.86 \\
\hline
\end{tabular}

${ }^{1}$ Unequal $\mathrm{n}$, largest SEM $(\mathrm{n}=3)$ reported.

pared with an inorganic $\mathrm{P}$ buffer, regardless of dietary $\mathrm{P}$ concentration. More extensive research is needed on the effect of diet on ruminal phytase activity.

\section{Feed Intake and Milk Yield}

Effect of starch source. Cows fed SF had a lower DMI compared with cows fed DG (Table 4), but starch source did not affect milk yield, or yield of protein, lactose, or SNF. Steam-flaking corn tended to increase milk yield efficiency (milk yield per kg of DMI; $P<0.07$ ) compared with DG (Table 4). In a review of 19 lactation trials, Theurer et al. (1999) found that cows fed steamflaked sorghum had similar feed intake and increased milk yield compared with those fed dry rolled sorghum, and that efficiency of milk yield was increased by an average of 5\%. This increase in efficiency of milk yield was similar in magnitude to that observed in the current study ( $+5.3 \%)$, although the reason for our observation (decreased DMI with constant milk yield) was the opposite of that usually observed.

Wheras the most common response to steam flaking in published research is increased milk yield with constant DMI, decreased DMI with constant milk yield was observed in midlactation cows fed steam-flaked sorghum grain (360 g/L) compared with those fed dryrolled sorghum (Santos et al., 1997). Efficiency of milk yield was increased by $16 \%$ in cows fed the steam-flaked sorghum diet in the Santos et al. (1997) study. Decreased DMI with more rapidly fermented starch sources was also observed in early lactation (Moore et al., 1992) and midlactation (Oliveira et al., 1993) cows fed steam-flaked sorghum in place of dry rolled sorghum.

The decrease in DMI observed in some studies with diets with more ruminally degraded starch may be due to a number of factors. One possible mechanism is more rapid postprandial accumulation of acid in the rumen and an increase in fluctuation of ruminal $\mathrm{pH}$ (Robinson and Kennelly, 1988). In the current study, however, there was no effect of starch source on total VFA concentration or ruminal $\mathrm{pH}$, and no time $\times$ treatment interaction for these measures (Table 5, Figures 3 and 4, discussed below). The disparity in research results may be explained by differences in the quantity of starch consumed, the grain type that processing treatment is applied to, and forage type; most of the studies reviewed by Theurer et al. (1999) included diets with alfalfa hay

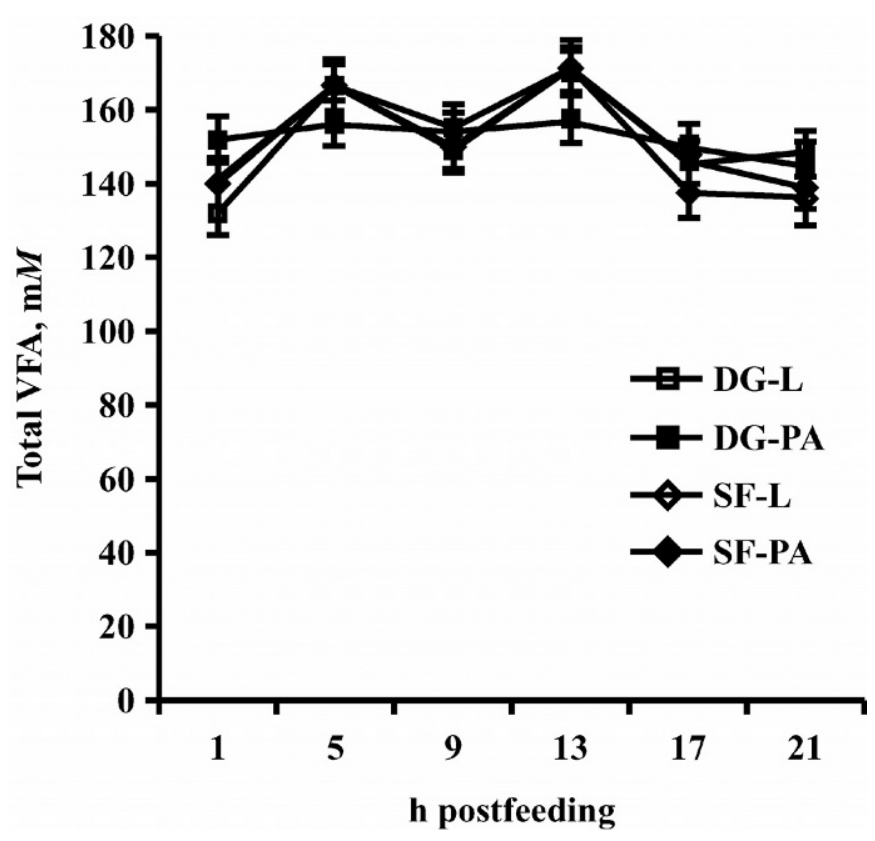

Figure 3. Effect of starch source and supplemental phytic acid on total VFA concentrations by time postfeeding in four lactating Holstein cows. DG-L = dry grain low; DG-PA = dry grain phytic acid; SF-L = steam flaked low; and SF-PA = steam flaked phytic acid. 


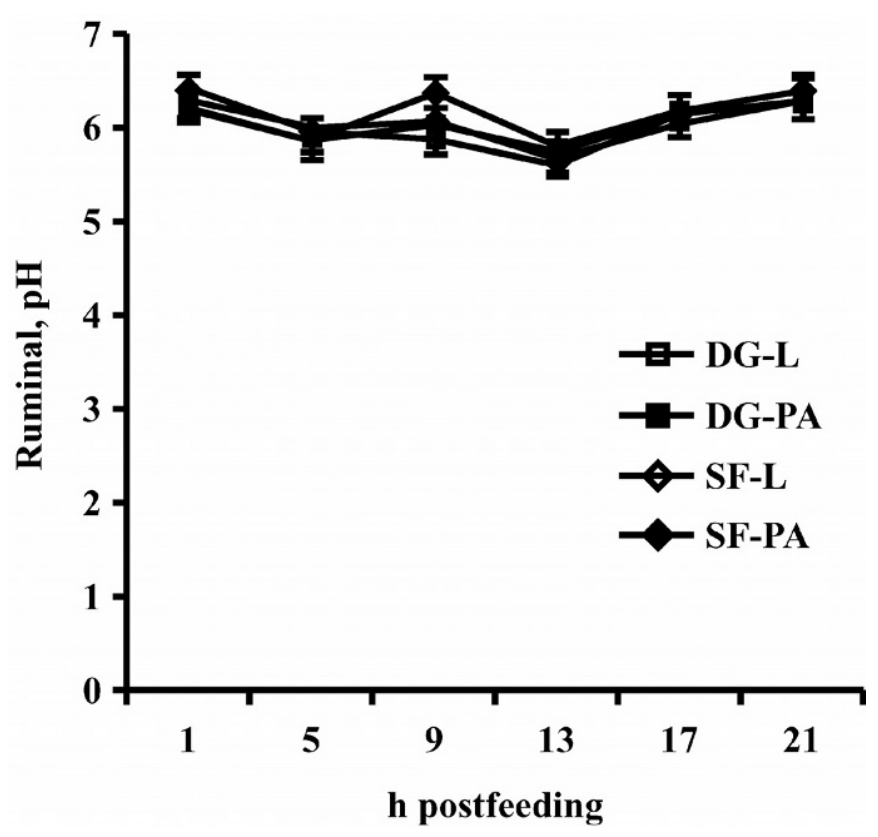

Figure 4. Effect of starch source and supplemental phytic acid on ruminal $\mathrm{pH}$ by time postfeeding in four lactating Holstein cows. DG$\mathrm{L}=$ dry ground low; DG-PA = dry ground phytic acid; $\mathrm{SF}-\mathrm{L}=$ steam flaked low; and SF-PA = steam flaked phytic acid.

as the principal forage, whereas diets in the current study contained alfalfa and corn silage.

Cows fed SF had decreased milk fat yield (Table 5) and concentration (data not shown) compared with cows fed DG corn. Previous studies also reported decreased milk fat yield and concentration when cows were fed SF corn compared with cows fed dry rolled or DG corn (Plascencia and Zinn, 1996; Crocker et al., 1998; Dhiman et al., 2002).

Effect of phytic acid supplementation. Supplementation of the diet with PA did not affect DMI (Table 4). Similarly, Wu et al. (2000) and Knowlton and Herbein (2002) observed no effect of $\mathrm{P}$ supplementation on DMI in dairy cattle. Decreased DMI was observed when lactating dairy cows were fed a diet deficient in $\mathrm{P}$ over two lactations (Valk and Sebek, 1999). Ternouth (1990) suggested that P-deficient diets may affect activity of ruminal microorganisms, which in turn would decrease DMI.

Supplementation with PA had no effect on yield of milk or milk components (Table 4), and there was no effect of the interaction of starch source and PA supplementation on DMI, or yield of milk and milk components. Several studies have reported no effect of dietary $\mathrm{P}$ concentration on milk yield or milk composition (Brintrup et al., 1993; Wu et al., 2000; Knowlton and Herbein, 2002), and Knowlton et al. (2001) observed no effect of milk yield or milk composition when diets were supplemented with wheat bran (an organic P source) or mono- and di-calcium phosphate (an inorganic $\mathrm{P}$ source). Valk and Sebek (1999) and Wu et al. (2001) reported a decrease in milk production and milk fat yield when cows were fed diets deficient in $\mathrm{P}$ for two or three lactations.

\section{Ruminal VFA and pH}

Effect of starch source. Cows fed SF had increased ruminal concentrations of propionate and butyrate, decreased ruminal acetate, and reduced acetate to propionate ratio compared with cows fed DG (Table 5). Concentrations of isobutyrate, isovalerate, valerate, and total VFA were not affected by starch source. No time of sampling $\times$ treatment interactions were observed. Treatment means for total VFA concentrations at each sampling time are presented in Figure 3. In other studies with lactating cows, SF corn diets increased ruminal propionate concentrations and decreased acetate-topropionate ratio compared with dry rolled corn (Plascencia and Zinn, 1996; Joy et al., 1997; Crocker et al., 1998). Crocker et al. (1998) reported an increase in ruminal butyrate concentration in Holstein cows fed SF corn diets compared with dry rolled corn.

Starch source had no effect on ruminal $\mathrm{pH}$ (mean = 6.10; Table 5). Whereas sampling was limited to times representing every $4 \mathrm{~h}$ of a 24 -h period, there was no interaction of time of sampling with treatment on ruminal $\mathrm{pH}$; treatment means at each sampling time are presented in Figure 4. Ruminal pH and A:P ratios were relatively high for all diets, reflecting the high forage content of treatment diets. This high forage content may have helped prevent a decline in ruminal $\mathrm{pH}$ with SF corn. Zinn et al. (1995) observed a decline in ruminal $\mathrm{pH}$ when Holstein steers were fed SF corn compared with dry rolled corn. Others have reported numerically, but not significantly, lower ruminal $\mathrm{pH}$ when lactating cows were fed SF corn compared with dry rolled corn (Plascencia and Zinn, 1996; Joy et al., 1997).

Effect of phytic acid supplementation. Supplementation with PA had no effect on ruminal $\mathrm{pH}$, total VFA concentration, acetate-to-propionate ratio, or concentrations of acetate, propionate, isobutyrate, butyrate, isovalerate, and valerate (Table 5). No published research has reported the effect of dietary $\mathrm{P}$ on ruminal VFA concentration. No effect of the interaction of starch source and phytic acid supplementation was observed on ruminal VFA or $\mathrm{pH}$.

\section{Nutrient Intake and Digestion}

Effect of starch source. Cows fed SF had significantly greater apparent total tract DM digestibility and 
Table 6. Effect of starch source and supplemental phytic acid (PA) on nutrient intake and total tract apparent digestibility in eight lactating Holstein cows.

\begin{tabular}{|c|c|c|c|c|c|c|c|c|}
\hline & \multicolumn{2}{|c|}{ Dry ground corn } & \multicolumn{2}{|c|}{ Steam-flaked corn } & \multirow[b]{2}{*}{$\mathrm{SEM}^{1}$} & \multicolumn{3}{|c|}{$P<$} \\
\hline & Low $\mathrm{P}$ & $\mathrm{PA}$ & Low $\mathrm{P}$ & $\mathrm{PA}$ & & Starch & $\mathrm{P}$ & Starch $\times P$ \\
\hline DM digestibility, \% & 66.9 & 67.1 & 70.4 & 69.4 & 0.94 & 0.01 & 0.63 & 0.54 \\
\hline Digested DM, kg/d & 16.8 & 17.7 & 17.0 & 16.5 & 0.79 & 0.45 & 0.85 & 0.29 \\
\hline Starch intake, $\mathrm{kg} / \mathrm{d}$ & 6.58 & 6.75 & 6.21 & 6.30 & 0.29 & 0.17 & 0.67 & 0.90 \\
\hline Starch digestibility, \% & 97.6 & 97.5 & 98.9 & 99.1 & 0.40 & 0.01 & 0.87 & 0.80 \\
\hline NDF digestibility, $\%$ & 41.5 & 43.1 & 43.5 & 45.4 & 0.47 & 0.64 & 0.70 & 1.00 \\
\hline
\end{tabular}

${ }^{1}$ Unequal $n$, largest SEM $(\mathrm{n}=7)$ reported.

total tract starch digestibility than those fed DG (Table 6). Fiber digestibility and digested DM $(\mathrm{kg} / \mathrm{d})$ were not affected by the starch source (Table 6). Similarly, Santos et al. (1999) saw an increase in DM digestibility when Holstein cows were fed SF corn in place of steamrolled corn or steam-flaked sorghum diets. Steam flaking of cereal grains disrupts the protein matrix surrounding starch granules, allowing the ruminal microorganisms increased access to amylose and amylopectin molecules (Kotarski et al., 1992).

Observed total tract starch digestibility values were very high for all treatments. Site of starch digestion (rumen vs. small intestine vs. large intestine) was not measured in this study, but may have varied with starch source. In duodenally- and ileally-cannulated lactating cows, starch disappearance from the large intestine was higher in cows fed dry corn than in those fed high moisture corn (Knowlton et al., 1998). Differences in site of starch digestion, if they occurred, would influence postabsorptive nutrient availability more than is indicated by the relatively high total tract starch digestibilities observed with DG and SF corn.

Effect of phytic acid supplementation. Supplementation of the diet with PA did not affect digestibility of DM, starch, and fiber digestibility (Table 6). There were no effects of the interaction of starch source and PA supplementation on nutrient digestibility.

\section{Ruminal Nutrient Pool Size and Turnover Time}

Effect of starch source. Dietary starch source had no effect on ruminal pool size or turnover time of DM or NDF (Table 7). Starch source did not affect pool size of $\mathrm{P}$ in the rumen, despite the large difference in $\mathrm{P}$ intake (102.1 vs. $86.5 \mathrm{~g} / \mathrm{d} \mathrm{P}$ intake for DG and SF corn, respectively, Table 3). Pool size of any nutrient in the rumen is the balance between inflow of that nutrient to and outflow from the ruminal pool. Inputs to the ruminal pool of $\mathrm{P}$ are consumed dietary $\mathrm{P}$ and salivary $\mathrm{P} ; \mathrm{P}$ exits the ruminal pool via passage. The increased $\mathrm{P}$ intake with constant ruminal pool size in cows fed DG yielded a tendency for a shorter ruminal turnover time of $\mathrm{P}$ compared with cows fed SF $(P<0.10)$. This constant $\mathrm{P}$ pool size and decrease in turnover time is either due to decreased salivary recycling of $\mathrm{P}$ in cows fed DG, or to increased rate of passage of $P$ from the rumen in these cows. There is no biologically apparent explanation for either, and the difficulty in obtaining representative samples of rumen contents is a caution against overinterpretation of this data.

Effect of phytic acid supplementation. Ruminal pool size of $\mathrm{P}$ tended to be higher in cows fed the PA diets compared with the low $\mathrm{P}$ diets $(P<0.07$; Table 7). Pool size of $P$ did not increase with $P A$ supplementation as much as did $\mathrm{P}$ intake, however, and ruminal $\mathrm{P}$

Table 7. Effect of starch source and supplemental phytic acid (PA) on ruminal nutrient pool size and turnover time in four lactating Holstein cows.

\begin{tabular}{|c|c|c|c|c|c|c|c|c|}
\hline & \multicolumn{2}{|c|}{ Dry ground corn } & \multicolumn{2}{|c|}{ Steam-flaked corn } & \multirow[b]{2}{*}{$\mathrm{SEM}^{1}$} & \multicolumn{3}{|c|}{$P<$} \\
\hline & Low $\mathrm{P}$ & $\mathrm{PA}$ & Low $\mathrm{P}$ & $\mathrm{PA}$ & & Starch & $\mathrm{P}$ & Starch $\times P$ \\
\hline $\mathrm{n}$ & 4 & 4 & 3 & 4 & & & & \\
\hline \multicolumn{9}{|c|}{ Ruminal pool size } \\
\hline $\mathrm{DM}, \mathrm{kg}$ & 9.20 & 9.64 & 8.97 & 9.83 & 0.92 & 0.98 & 0.32 & 0.74 \\
\hline NDF, kg & 5.22 & 5.45 & 4.65 & 5.31 & 0.69 & 0.51 & 0.42 & 0.68 \\
\hline $\mathrm{P}, \mathrm{g}$ & 59.5 & 66.1 & 54.7 & 63.5 & 4.98 & 0.30 & 0.07 & 0.75 \\
\hline \multicolumn{9}{|c|}{ Ruminal turnover time, $\mathrm{h}$} \\
\hline DM & 9.04 & 9.29 & 9.57 & 10.1 & 0.79 & 0.33 & 0.57 & 0.85 \\
\hline NDF & 17.4 & 17.7 & 19.1 & 18.0 & 2.96 & 0.73 & 0.88 & 0.79 \\
\hline $\mathrm{P}$ & 16.9 & 14.3 & 21.3 & 15.5 & 1.79 & 0.10 & 0.03 & 0.31 \\
\hline
\end{tabular}

${ }^{1}$ Unequal $n$, largest SEM $(\mathrm{n}=3)$ reported. 
turnover time was shorter (14.9 vs. $19.1 \mathrm{~h}$ for PA and Low $\mathrm{P}$, respectively). There are no published studies that report ruminal pool size of $\mathrm{P}$, but Evans and Davis (1966) observed an increased P concentration in ruminal fluid of steers fed high $\mathrm{P}$ diets compared with low $\mathrm{P}$ diets. The increase in ruminal $\mathrm{P}$ pool size may be explained by increased $\mathrm{P}$ intake, increased recycling of salivary $\mathrm{P}$ to the rumen, or decreased rate of passage of $\mathrm{P}$ from the rumen. Intake of $\mathrm{P}$ was higher in cows fed PA, and Challa et al. (1988) reported an increase in salivary $\mathrm{P}$ secretion in calves fed diets containing more P. Supplementation with PA did not affect ruminal pool size of NDF, and no effect of the interaction of starch source and PA supplementation was observed on ruminal pool size or turnover time of any nutrient.

\section{CONCLUSIONS}

Excretion of $\mathrm{P}$ was reduced and partitioning of consumed $\mathrm{P}$ to milk was increased when cows were fed SF corn. Ruminal phytase activity was not affected by the main effect of starch source or PA supplementation, but an interaction observed between the main effects indicates that diet may affect phytase activity. Cows fed SF had lower DMI, similar milk yield, and improved efficiency of milk yield compared with cows fed DG. Altering starch source to improve efficiency of milk yield in lactating dairy cows may help reduce $\mathrm{P}$ losses from dairy farms.

\section{ACKNOWLEDGMENTS}

Financial support for this project was provided by Loveland Industries (Greeley, CO), and Pennfield Corporation (Lancaster, PA). The authors appreciate the input of Carl Polan, Tim Snyder, Charlie Cobb, and Ken Wilson, and the technical support provided by Harold Nester, Chuck Miller, William Saville, and Wendy Wark. Assistance provided by Gary Brauning, Kristin Burkholder, Gwenn Catterfeld, Rebecca Cornman, David Griffith, Elizabeth Keene, Janeen Lewis, and Kristi Seat during the collection periods and sample analysis is sincerely appreciated.

\section{REFERENCES}

AOAC. 1984. Official Methods of Analysis. 14th ed. Arlington VA. BASF. 1996. Determination of phytase activity. Mt. Olive, NJ.

Brintrup, R., T. Mooren, U. Meyer, H. Spiekers, and E. Pfeffer. 1993. Effects of two levels of phosphorus intake on performance and faecal phosphorus excretion of dairy cows. J. Anim. Physiol. Anim. Nutr. 69:29-36.

Challa, J., and G. D. Braithwaite. 1988. Phosphorus and calcium metabolism in growing calves with special emphasis on phosphorus homeostasis. J. Agri. Sci. (Camb.) 110:573-581.

Crocker, L. M., E. J. DePeters, J. G. Fadel, H. Perez-Monti, S. J. Taylor, J. A. Wyckoff, and R. A. Zinn. 1998. Influence of processed corn grain in diets of dairy cows on digestion of nutrients milk composition. J. Dairy Sci. 81:2394-2407.

Dhiman, T. R., M. S. Zaman, I. S. MacQueen, and R. L. Boman. 2002. Influence of corn processing and frequency of feeding on cow performance. J. Dairy Sci. 85:217-226.

Evans, J. L., and G. K. Davis. 1966. Dietary phosphorus, sulfur, and molybdenum and mineral composition of rumen fluid. J. Anim. Sci. 25:1010-1013.

Glenn, B. P., T. E. Dawson, A. M. Lefcourt, and V. A. Wilkerson. 1998. Effect of level of high moisture corn in alfalfa-based rations on starch digestion by mid lactation cows. J. Anim. Sci. 76(Suppl. 1):336. (Abstr.)

Godoy, S., and F. Meschy. 2001. Utilization of phytate phosphorus by rumen bacteria in a semi-continuous culture system (Rusitec) in lactating dairy goats fed on different forage to concentrate ratios. Reprod. Nutr. Dev. 41:259-265.

Guyton, A. D., K. F. Knowlton, D. P. Casper, B. P. Glenn, and V. A. Wilkerson. 2000. Starch source affects phosphorus excretion in lactating dairy cows. J. Dairy Sci. (Suppl. 1):288. (Abstr.)

Holm, J., I. Bjorck, A. Drews, and N. G. Asp. 1986. A rapid method for the analysis of starch. Starch 7:224-226.

Joy, M. T., E. J. DePeters, J. G. Fadel, and R. A. Zinn. 1997. Effects of corn processing on the site and extent of digestion in lactating cows. J. Dairy Sci. 80:2087-2097.

Knowlton, K. F., B. P. Glenn, and R. A. Erdman. 1998. Performance, rumen fermentation, and site of starch digestion in early lactation cows fed corn grain harvested and processed differently. J. Dairy Sci. 81:1972-1984.

Knowlton, K. F., and J. H. Herbein. 2002. Phosphorus balance during early lactation in dairy cows fed diets varying in phosphorus content. J. Dairy Sci. 85:1227-1236.

Knowlton, K. F., J. H. Herbein, M. A. Meister-Weisbarth, and W. A. Wark. 2001. Nitrogen and phosphorous partitioning in lactating Holstein cows fed different sources of dietary protein and phosphorus. J. Dairy Sci. 84:1210-1217.

Kotarski, S. F., R. D. Waniska, and K. K. Thurn. 1992. Starch hydrolysis by the rumen microflora. J. Nutr. 122:178-190.

Moore, J. A., M. H. Poore, T. P. Eck, R. S. Swingle, J. T. Huber, and M. J. Arana. 1992. Sorghum grain processing and buffer addition for early lactation cows. J. Dairy Sci. 75:3465-3472.

Morse, D., H. Head, C. J. Wilcox, H. H. V. Horn, C. D. Hissem, and B. Harris, Jr. 1992a. Effects of concentration of dietary phosphorous on amount and route of excretion. J. Dairy Sci. 75:3039-3049.

Morse, D., H. H. Head, and C. J. Wilcox. 1992b. Disappearance of phosphorous in phytate from concentrates in vitro from rations fed to lactating dairy cows. J. Dairy Sci. 75:1979-1986.

National Research Council. 1989. Nutrient Requirements of Dairy Cattle. 6th rev. ed. Natl. Acad. Sci., Washington, DC.

National Research Council. 2001. Nutrient Requirements of Dairy Cattle. 7th rev. ed. Natl. Acad. Sci., Washington, DC.

Nelson, T. S., L. W. Ferrara, and N. L. Storer. 1968. Phytate phosphorus content of feed ingredients derived from plants. Poult. Sci. 47:1372-1374.

Oliveira, J. S., J. T. Huber, D. Ben-Ghedalia, R. S. Swingle, C. B. Theurer, and M. Pessarakli. 1993. Influence of sorghum grain processing on performance of lactating dairy cows. J. Dairy Sci. 76:575-581.

Plascencia, A., and R. A. Zinn. 1996. Influence of flake density on the feeding value of steam-processed corn in diets for lactating cows. J. Anim. Sci. 74:310-316.

Robinson, P. H., and J. J. Kennelly. 1988. Influence of ammoniation of high moisture barley on its in situ rumen degradation and influence on rumen fermentation in dairy cows. Can. J. Anim. Sci. 68:839-851.

Santos, F. A. P., J. T. Huber, C. B. Theurer, R. S. Swingle, Z. Wu, J. M. Simas, K. F. Chen, S. C. Chan, J. Santos, and E. J. DePeters. 1997. Comparison of barley and sorghum grain processed at different densities for lactating dairy cows. J. Dairy Sci. 80:20982103.

Santos, J. E. P., J. T. Huber, C. B. Theurer, L. G. Nussio, M. Tarazon, and F. A. P. Santos. 1999. Response of lactating dairy cows to steam-flaked sorghum, steam-flaked corn, or steam-rolled corn 
and protein sources of differing degradability. J. Dairy Sci. 82:728-737.

SAS Institute. 1999. SAS Users Guide, Version 8.0. Cary, NC.

Sims, J. T., R. R. Simard, and B. C. Joern. 1998. Phosphorus loss in agricultural drainage: Historical perspective and current research. J. Environ. Qual. 27:277-293.

Smith, R. A., and R. B. Alexander. 2000 Sources of nutrients in the nation's watersheds. Managing nutrients and pathogens from animal agriculture, Camp Hill, PA, Natural Resource, Agriculture, and Engineering Service (NRAES).

Ternouth, J. H. 1990. Phosphorus and beef production in Northern Australia. Trop. Grasslands 24:159-169.

Theurer, C. B., J. T. Huber, A. Delgado-Elorduy, and R. Wanderley. 1999. Invited review: Summary of steam-flaking corn or sorghum grain for lactating dairy cows. J. Dairy Sci. 82:1950-1959.

Valk, H., and L. B. J. Sebek. 1999. Influence of long-term feeding of limited amounts of phosphorus on dry matter intake, milk production, and body weight of dairy cows. J. Dairy Sci. 82:2157-2163.

Van Soest, P. J., J. B. Robertson, and B. A. Lewis. 1991. Methods for dietary fiber, neutral detergent fiber, and nonstarch polysac- charides in relation to animal nutrition. J. Dairy Sci. 74:35833597.

Virginia Poultry Waste Management Program. 1999. Virginia Code. 62.1-44.17:1.1.

Water Quality Improvement Act of 1998. Maryland Agriculture Code. 8-801.1.

Wu, Z., and L. D. Satter. 2000. Milk production and reproductive performance of dairy cows fed two concentrations of phosphorus for two years. J. Dairy Sci. 83:1052-1063.

Wu, Z., L. D. Satter, A. J. Blohowiak, R. H. Stauffacher, and J. H. Wilson. 2001. Milk production, estimated phosphorus excretion, and bone characteristics of dairy cows fed different amounts of phosphorus for two or three years. J. Dairy Sci. 84:1738-1748.

Wu, Z., L. D. Satter, and R. Sojo. 2000. Milk production, reproductive performance, and fecal excretion of phosphorus by dairy cows fed three amounts of phosphorus. J. Dairy Sci. 83:1028-1041.

Yanke, L. J., H. D. Bae, L. B. Selinger, and K. J. Cheng. 1998. Phytase activity of anaerobic ruminal bacteria. Microbiology 144:15651573.

Zinn, R. A., C. F. Adam, and M. S. Tamayo. 1995. Interaction of feed intake level on comparative ruminal and total tract digestion of dry-rolled and steam-flaked corn. J. Anim. Sci. 73:1239-1245. 